\title{
Formation of New Territories in Residents' House in Tourism Kampung
}

\author{
Vincentia Aprilia Devi Ratnasari, Happy Ratna Sumartinah and Dewi Septtanti \\ Department of Architecture, Institut Teknologi Sepuluh Nopember, Surabaya \\ e-mail: happyrs@arch.its.ac.id
}

\begin{abstract}
Abstrak - Changing an ordinary kampung into a tourist kampung will provide changes in every aspect of the kampung. These changes are among the changes in terms of social, economic, cultural, environmental, and activities in the tourist kampung. Through the change of activities automatically forms a new regulatory system in its spatial and function. then comes the urge of citizens to maintain and form a private territory to other activities (tourist activities). so it needs to know how the villagers form their new territory in the outer space of their dwelling to get the comfort and privacy that suits their needs.

The method used to determine the formation of new territories carried out by citizens using studies from research that raised similar phenomena that have occurred. After that, a comparison is made with field data or the current conditions of the current tourist kampung. The results obtained will find the form of citizens' efforts to form new territories with their boundaries. The boundaries are adjusted to the factors that shape it such as space requirements, spatial functions, activities, and the perpetrators of these activities. Then it can be used to indicate other changes that occur in the tourist kampung.
\end{abstract}

Kata Kunci-Changes, Outdoor Spaces, System Of Activities, System Of Settings, Territories, Tourist Kampungs.

\section{INTRODUCTION}

ACCORDING to data obtained by UNWTO, tourism is one of the fast-growing economic sectors and has a good impact on development [1]. oreign exchange income in the economic sector is the largest source for the country, especially for Indonesia. Besides in the economic sector, tourism also has a positive impact on the socio-cultural sector and also the environment [2]. Through these positive impacts, it becomes an important strategy to be able to solve several problems.

One problem that has occurred in the slum in Semarang City. This problem was solved by using a tourism village development strategy implemented in 2015. Through the use of this strategy, it was intended that the village which was originally a slum turned more organized, organized, safe, and comfortable because it was prepared to become a tourist attraction. In addition, the strategy includes the Poverty and Unemployment Joint Movement Program through Economic Harmonization, Education, Ecosystems and the Common Ethos of the Community, or often abbreviated as "GERBANG HEBAT", the strategy is considered to be very effective, especially in improving slums into a thematic village and also has its own potential for tourism in the city of Semarang [3].

Slums that become one of the locations for implementing the tourism village development strategy are Wonosari Village, Randusari Village, South Semarang District, Semarang City. The location of Wonosari village, now known as Kampong Pelangi, can be shown in Figure 1. Changing Wonosari village to become a tourist village can cause changes to the economic, social, cultural, and environmental structure. It also affects the mindset, cognition, personal area, comfort, activity, and ownership boundaries of the villagers to be able to shape and change the space around their dwellings, especially on the terrace of the house. The shape of the change is related to the formation of new territorial structures on the porch of the house. The territory is an embodiment of spatial boundaries formed by homeowners who experience the activities of others to achieve comfort and personal space [4]. So this research will raise the issue of the formation of new territories on the terraces of community homes due to the development of tourism in the village. The purpose of this study was to determine the shape of the new territory that occurred and see the factors affecting the development of tourist villages that influence them.

The territory is the limit where living things determine their desires, mark, and defend them, especially from the possibility of intervention from other parties [4]. Territorial strategies are more than just guidelines for an area to meet their physical needs, but also for emotional and cultural needs. Relating to emotional needs, territorial strategies relate to issues concerning private and public space, as well as strategies regarding privacy. Territorial strategy can also be interpreted as a series of behaviors and thoughts or cognitions displayed by individuals or groups, based on an understanding of the ownership of physical space, so that territory can be interpreted as a physical boundary that limits between individuals or groups in interacting [5]. Territorial function refers to interrelated systems of attitudes, sentiments, and behaviors that have access to what specific spaces and activities occur in that space. So it can be concluded that the understanding of territory is the behavior and cognition naturally of a person or group that marks, maintains, and set limits on other parties for ownership of spatial physical settings.

Three broad elements of the territorial function system include attitudes (responsibility, the vigilance of control), behavior (responding to intrusions or potential intrusions, exercising control over activities in the area), and markers (signs, ornaments, etc.). If territoriality functions as a system, individuals or blocks that are "high" in one of these components must be "high" in the other components. This is because each component is interrelated and influences each other [6]. Territorial functioning functions as a system; namely, that attitudes and behaviors can work together to strengthen one another. On-block and off-block 
The $6^{\text {th }}$ International Seminar on Science and Technology (ISST) 2020

July $25^{\text {th }} 2020$, Institut Teknologi Sepuluh Nopember, Surabaya, Indonesia

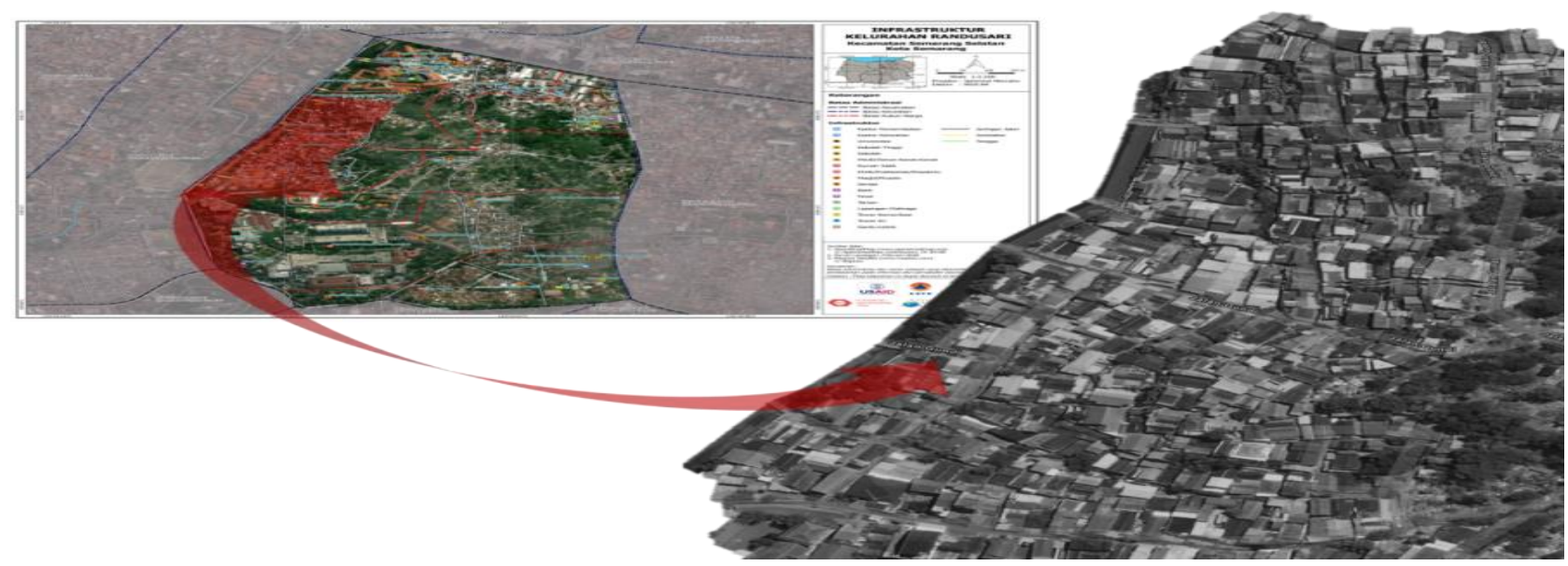

Figure 1. Location of Wonosari Village / Kampung Pelangi.

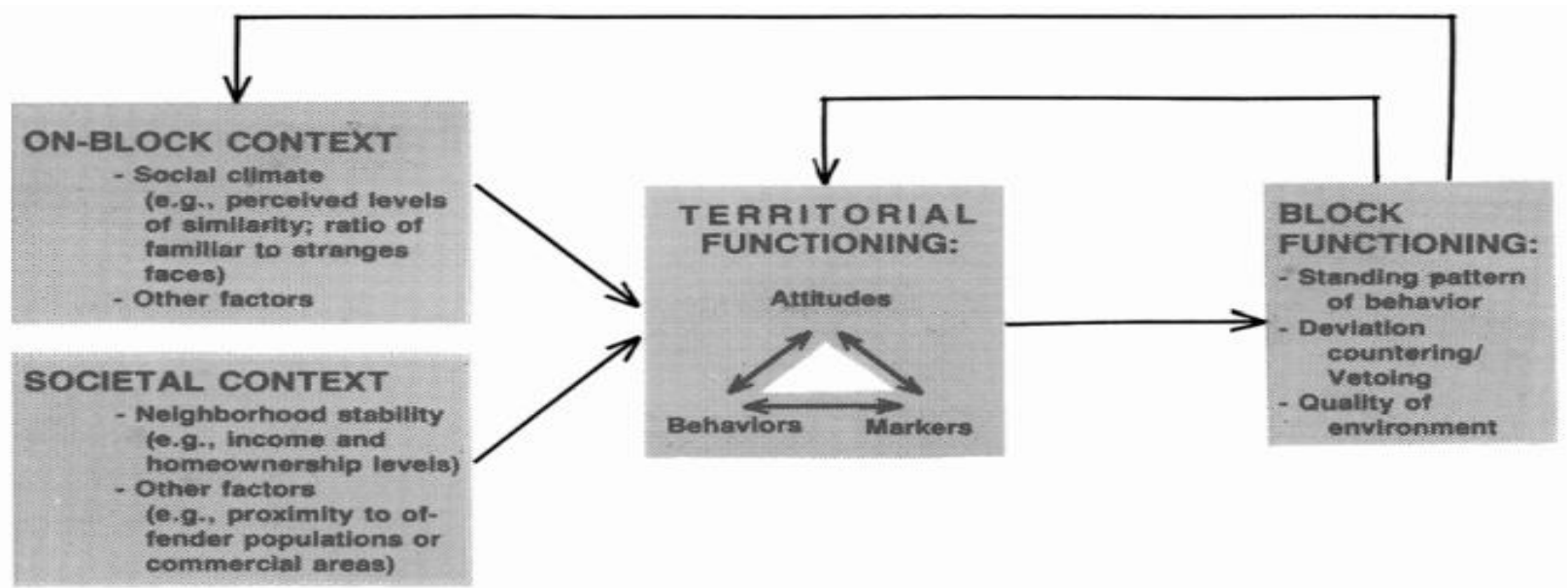

Figure 2. General outline of the determinants and consequences of local territorial functions.

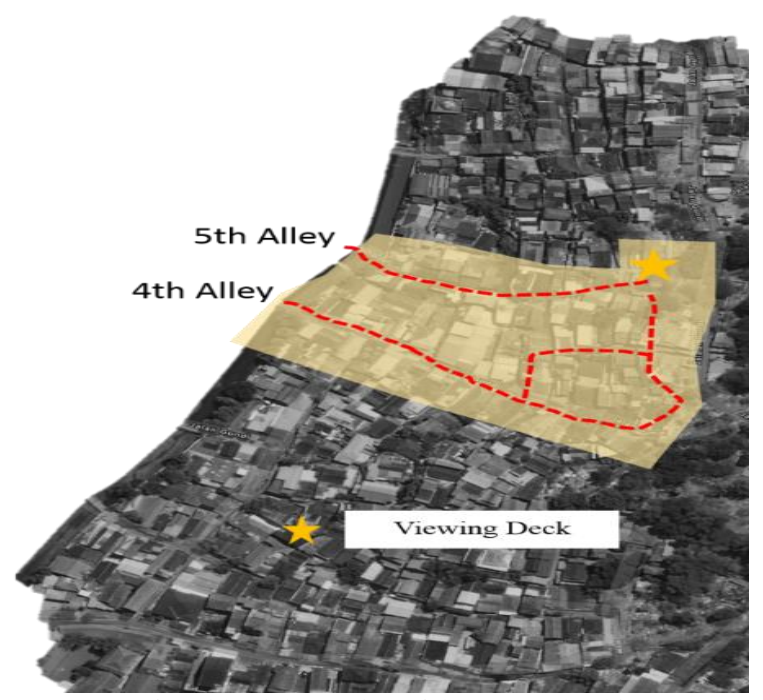

Figure 3. Map of Residential Location of the Research Object.

environmental factors can affect territorial function. These points are illuminated by the analysis of individual territorial cognition. As explained in Figure 2.

\section{METHOD}

The research was conducted through direct assessment of phenomena that occur in the object of study. The information obtained is explored and collected by way of observation, mapping, and interview. Observations, mappings, and interviews were carried out on several dwellings that often occur interactions and activities between residents and visitors in Kampung Pelangi, so this method is a qualitative method. Qualitative research often understood as a subjective understanding compared to an absolute understanding so that the factual categorization becomes somewhat debated and is based on an individual or group perspective [7]. Qualitative research studies the things that happen to the environment around them and tries to understand or interpret the phenomenon in the meaning and meaning of people to them [8].

The object of the study was focused on alley 4 and 5 of Kampung Pelangi, Randusari Village, Semarang City. Determination of the location because based on observations shows that the alley has the intensity of more frequent visits and has more interaction activities between visitors and residents. Then the next focus is the outside space around the residence which facilitates the activities and interactions of residents and visitors. The focusing aims to find out the formation of new territories that occur in the outer space of residential residents. Based on this focus, there are several dwellings that will be sampled because they have changed and serve as a forum to facilitate tourist activities. The dwelling can be seen clearly in Figure 3. 
The $6^{\text {th }}$ International Seminar on Science and Technology (ISST) 2020

July $25^{\text {th }} 2020$, Institut Teknologi Sepuluh Nopember, Surabaya, Indonesia

Table 1.

Evaluation of Internal Factors Forming Occupancy Territories in Kampung Pelangi

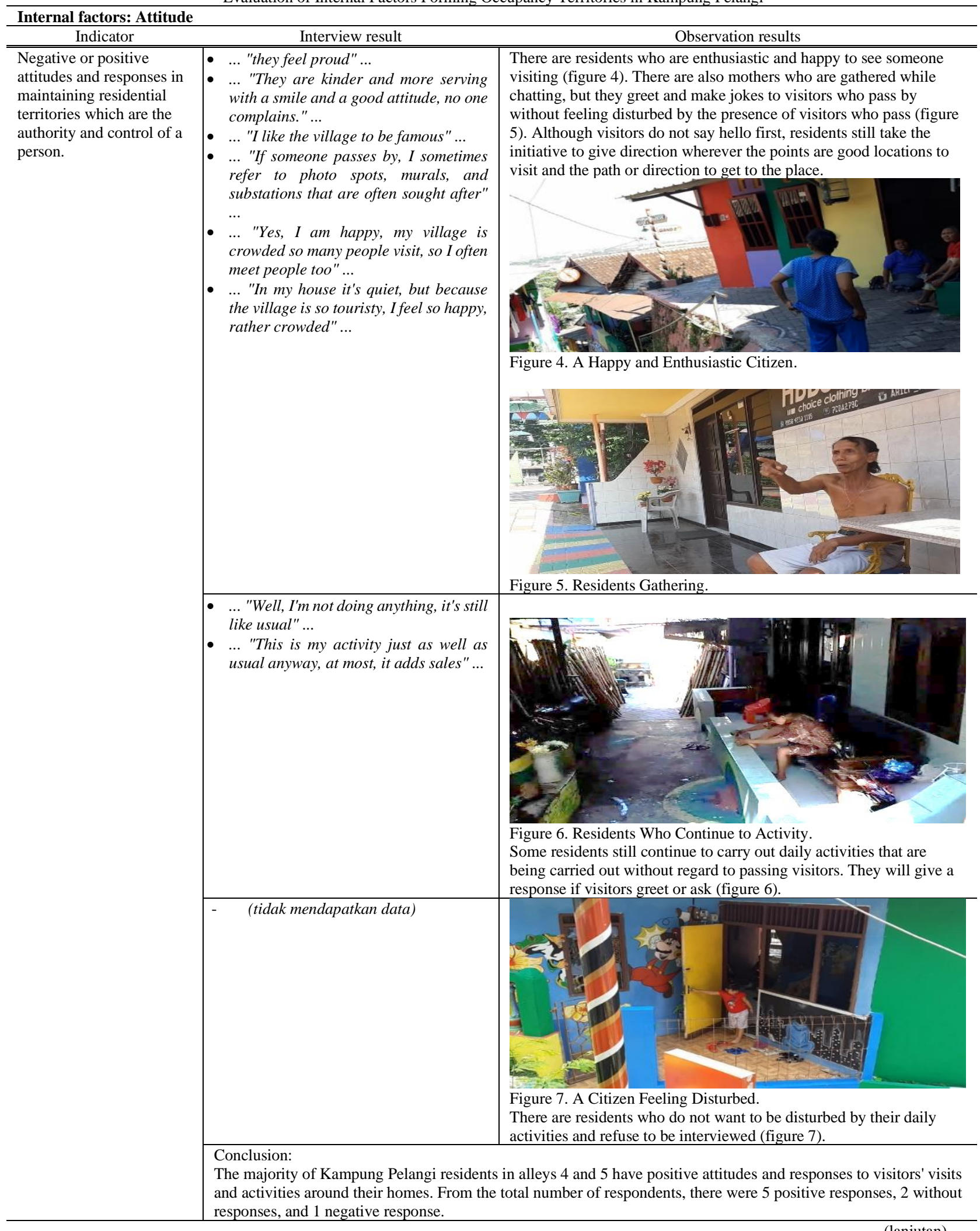

(lanjutan)

\section{RESULT AND DISCUSSION}

Changes in the structure of the territory is a form of transformation that occurs in the environment, can be in the form of adding elements which means that the built environment is experiencing growth; element reduction which means that the site has eroded/reduced; or changes in the position of the elements which means that the site has moved [9]. As happened in Kampung Pelangi , territorial changes occurred because there was a transformation from the village. The transformation in Kampung Pelangi as a built 
The $6^{\text {th }}$ International Seminar on Science and Technology (ISST) 2020

July $25^{\text {th }} 2020$, Institut Teknologi Sepuluh Nopember, Surabaya, Indonesia

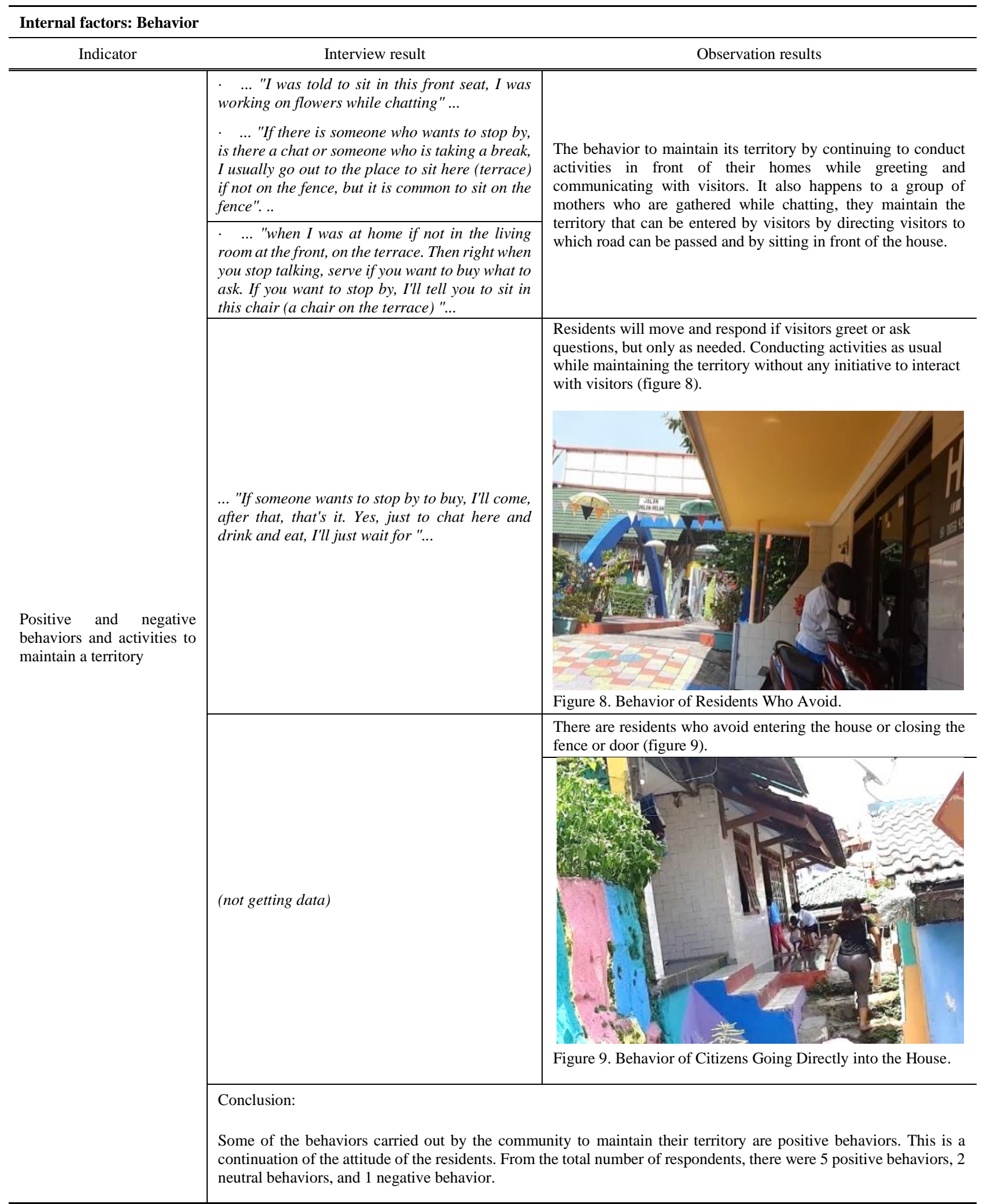

(lanjutan)

environment occurs because of internal factors that shape the territoriality. The forming factors are internal factors which consist of the three elements of the territorial function, namely attitudes, behaviors, and markers. While external or external factors that are related and affect the three elements of the territorial function are the on-block context that is directly related to the block functioning and the societal context.

\section{A. External Factors}

External or external factors that are related and affect the three elements of territorial function are the on-block context 
The $6^{\text {th }}$ International Seminar on Science and Technology (ISST) 2020

July $25^{\text {th }} 2020$, Institut Teknologi Sepuluh Nopember, Surabaya, Indonesia

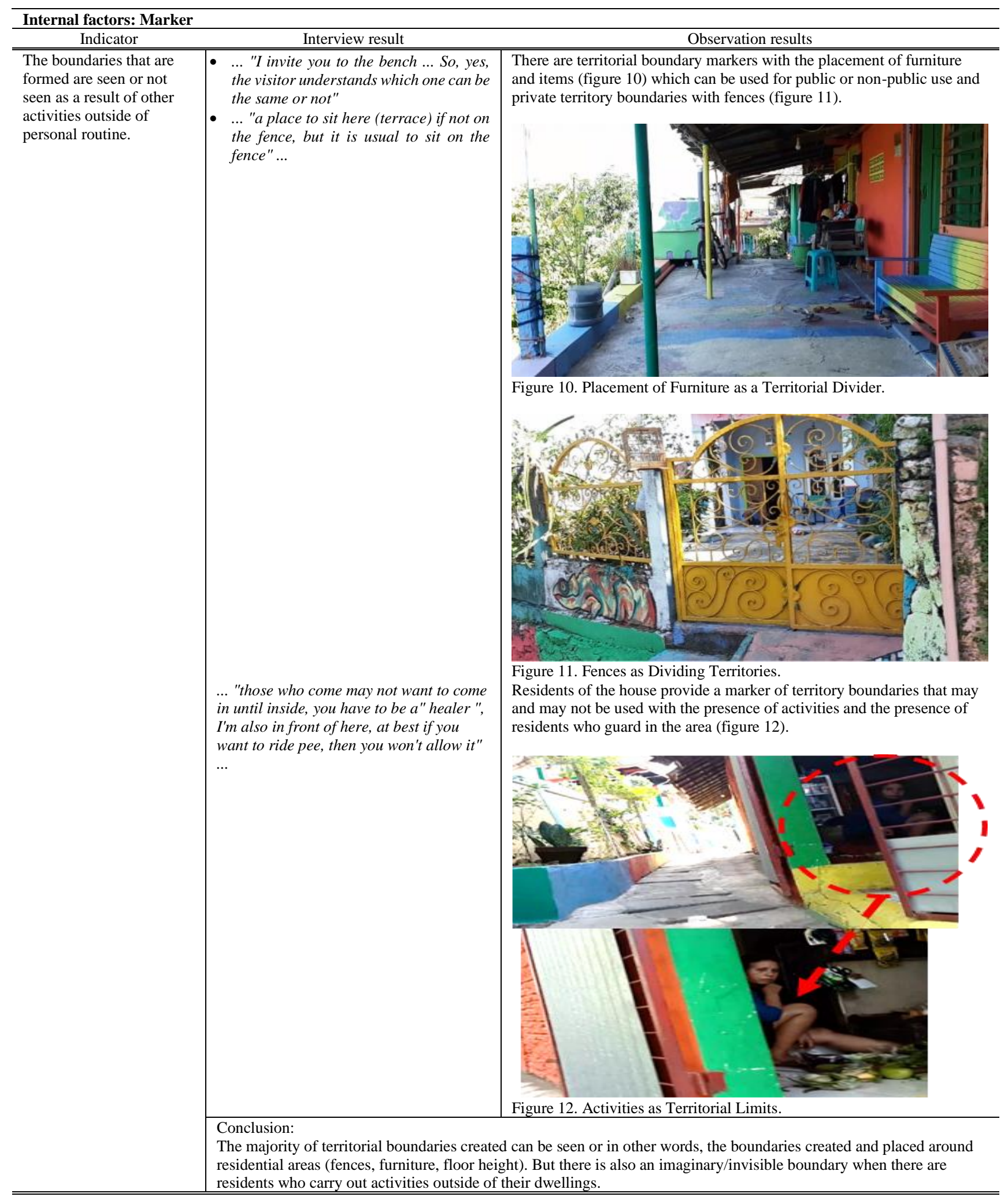

that is directly related to the block functioning and societal context.

\section{1) On-block context}

on-block context is an environmental factor that influences someone to maintain or form a territory, in this case, which includes such a social atmosphere (social climate) in a residential environment. Based on data from interviews with the head of RW 03 stated that.
"The people here are actually compact, there are routine activities from mothers, teenagers, to Pokdarwis(tourism management group)management. From the PKK (family welfare empowerment group)ladies, there is also another group that carries out souvenirs. But to maintain this village to keep it interesting it's hard sometimes they also have a sense of saturation and again constrained by capital as well. 
The $6^{\text {th }}$ International Seminar on Science and Technology (ISST) 2020

July $25^{\text {th }} 2020$, Institut Teknologi Sepuluh Nopember, Surabaya, Indonesia

But the role of the community here is good, if not the village doesn't turn out like this ",

Meanwhile, according to the head of PKK RT 02, the social atmosphere of the environment is

"Actually, the people here are compact, but sometimes the moods are too, sometimes some want to get involved because there is money. Yes, it is natural. But how come the citizens are well familiar, which isn't weird. There must be a driver to keep the spirit going. But so far there is no obstacle in the society."

From some of the information from the interview, results show that the condition of the social atmosphere of the environment in Kampung Pelangi is considered compact only sometimes there are fluctuations and obstacles in terms of personal and economic terms.

\section{2) Block functioning}

Block Functioning is a factor in which there is a pattern of overall community behavior that exists in the environment both deviations and resistance to changes in environmental quality that occur. Changing the quality of the environment that is the context in this study is a change in physical quality from ordinary and slum villages to more beautiful, comfortable, and beautiful tourist villages. These sub-factors strongly illustrate the unity of the three elements or subfactors of the territorial-forming internal factors that shape behavior patterns in response to changes in environmental quality in the residential environment. The environmental quality of Kampung Pelangi has gradually improved because the development of the village has made the community happy and accepted from the change of the village into tourism. With the change in the village, the community has contributed to changing the quality of the environment by changing its behavior patterns. In addition, the community is also more enthusiastic and accept the development of this village because of the certainty of the building land they have.

According to the results of interviews with the chairman of RW 03 stated that.

"They feel happier that there has been a kampung Pelangi. Their lifestyle has changed from throwing garbage in the river, so some of the waste has been recycled into souvenirs, then there is no more defecation on the riverbank as well, unemployment is also reduced because it is at the open shop."

The government has a program to certify land for the residents, because in the past this land was land for tombs, so the community became happier and safer because the house was already their own land.

Based on these facts it can be seen that the Semarang City government program and the private sector have a positive impact on each of its citizens and on the environment that is getting better.

\section{3) Societal Context}

Societal context explains how the social context of Kampung Pelangi influences a person in carrying out a response, behavior, and marking his territory. Social contexts to be discussed include the conditions of income and professional ranges, conditions of homeownership, and education. Based on data from the social context of Kampung Pelangi, it is shown that the majority work as private employees who earn in accordance with the Minimum Minimum Wage, but from interviews with some residents, most of the housewives have a while arranging paper flowers to supply the flower market in front of the village.

Meanwhile, according to the results of interviews conducted with the chairman of RW 03 that

"The community was happy because they received paint assistance from the government and CSR. The thing is they don't have the funds to fire, the price of paint is only around one million per million. They were very supportive by participating in firing and their lifestyle improved for the better. After painting, the people's demand for paint is higher for beautifying the outside of the house. But they also have the creativity to add their own trinkets from their own money and business."

This fact is also supported by the results of an interview with the Head of the Planning and Evaluation Subdivision of the Semarang City Housing and Settlement Office who said that.

"Previously, the Kampung Pelangi, whose name was Gunung Brintik / Wonosari, was a slum, many houses were unfit for habitation. The facilities of the lampstand also do not accommodate the residents. Yes, because the background of the people is from the middle-class economy as a laborer, it is difficult to be able to repair their own houses, let alone to improve their villages. Yes, besides that, most of their education is on average only high school. So the knowledge to develop the village is also lacking and because of the lack of information, they also get. "

The existence of these facts shows that the community at its economic level is less able to budget personal funds for the costs used to paint the village and beautify the village. So that if there is no interference from the government and CSR funds, the community is also reluctant to change the village. Besides, based on direct observation and interviews with several residents, they feel happy and encouraged to take the initiative to help the government in developing this Kampung Pelangi by making ornament trinkets from used goods.

\section{B. Internal Factors}

The change from Kampung Pelangi creates and shapes factors that influence the formation of new territories, both internal and external. The internal factors which are factors originating from within the individual themselves are related and influence each other to form a territorial function. These factors consist of three interrelated elements and influence one another, namely attitude and personality is the result of a person's response by reacting and evaluating an object or the environment around him in the form of an impartial or impartial attitude. The attitude itself is closely related and influenced by affection (feelings), thoughts (cognition), actions (cognation), and rejects or accepts (predisposition) [10]; behavior and activity is a manifestation of the results of a person's attitude towards an object and its environment in the form of actions and activities. Behavior and activity factors related to this territorial shift explain the behavior, habits, and activities undertaken to maintain their territory, in this case, the area is a residential area. The behavior of space users in social relations, which includes defense-related to 
The $6^{\text {th }}$ International Seminar on Science and Technology (ISST) 2020

July $25^{\text {th }} 2020$, Institut Teknologi Sepuluh Nopember, Surabaya, Indonesia

ownership. This behavior can be divided into several interrelated mechanisms namely: control, domination, aggression, personalization [11]; barrier/marker is a form or result of a person's behavior that serves to create territorial boundaries or areas within the authority or control.

\section{CONCLUSION}

With the discussion about the internal factors of forming territories, it can be concluded that the internal attitude, behavior, and marker factors are the embodiments of the results of a person's thoughts in dealing with changes by maintaining their territory. This can be seen in the change in the attitude of someone to conduct a behavior or activity to be able to provide boundaries or markers of the part of the area they control in other words marking their territory related to the change or transformation of the built environment. Then the new territory can be identified by its forming elements, namely attitude, behavior and markers. These elements can inform the existence of areas that are controlled, controlled, owned, or controlled by a person or group with responses, behaviors and boundaries created.

The new territorial shape is the result of changes in physical and non-physical settings due to the development of a tourist village. With the change in activity settings, it encourages changes in the village community's behavior, lifestyle, mindset, activities, and information. These changes cause a change in the need for comfort, privacy, and comfort so that people will form new territories around their homes.

\section{REFERENCES}

[1] World Tourism Organization, Sustainable Tourism for Development Guidebook - Enhancing capacities for Sustainable Tourism for development in developing countries. Madrid: World Tourism Organization (UNWTO), 2013.

[2] I. K. Suwena dan I. G. N. Widyatmaja, Pengetahuan Dasar Ilmu Pariwisata. Denpasar: Pustaka Larasan, 2017.

[3] B. K. Semarang, "PENANGGULANGAN KEMISKINAN KOTA SEMARANG.” Bappeda Kota Semarang, semarang, 2017.

[4] B. Setiawan dan Haryadi., Arsitektur Lingkungan dan Perilaku. Yogyakarta: Gadjah Mada University Press, 2010.

[5] A. Dwiantina, "Invasi Ruang Personal Dan Teritori Dalam Gedung Olahraga," Universitas Indonesia, 2011.

[6] R. B. Taylor dan S. Brower, "Home and Near-Home Territories," in Home Environments, I. Altman dan C. M. Werner, Ed. Boston, MA: Springer US, 1985, hal. 183-212.

[7] R. Lucas, Research Methods for Architecture. London: Laurence King, 2016.

[8] Linda N. Groat dan D. Wang, Architectural Research Methods, 2 ed. New Jersey: John Wiley \& Sons, 2013.

[9] E. S. Bukit, H. Hanan, dan A. S. Wibowo, "Aplikasi Metode N . J . Habraken pada Studi Transformasi,” J. Lingkung. Binaan Indones. V, vol. 1, no. 1, hal. 51-62, 2012.

[10] E. Pratama, "Dampak Pengembangan Pariwisata dan Sikap Nelayan di Desa Pangandaran," INSTITUT PERTANIAN BOGOR, 2013.

[11] Y. Setyoningrum dan Y. A. Pilliang, "Perubahan Teritorialitas Rumah Jawa di Kampung Batik Laweyan Surakarta Sebagai Industri Kreatif Pariwisata," in Seminar Nasional Ergonomi dan Kongres Nasional PEI, 2012. 